\title{
STRATEGI PENGEMBANGAN BANK SAMPAH DI WILAYAH DEPOK
}

STRATEGY DEVELOPMENT OF WASTE BANKS IN DEPOK AREA

\author{
Linda Fitrina Hasnam*1, Rizal Syarief**), dan Ahmad Mukhlis Yusuf ${ }^{* * *}$ ) \\ *) Sekolah Bisnis, Institut Pertanian Bogor \\ Jl. Raya Pajajaran, Bogor 16151 \\ **) Departemen Teknologi Pangan, Fakultas Teknologi Pertanian, Institut Pertanian Bogor \\ Jl. Lingkar Akademik, Kampus Dramaga, Bogor 16680 \\ $\left.{ }^{* *}\right)$ Magister Manajemen BINUS University \\ Jl. Syahdan No. 9 | Jakarta 11480
}

\begin{abstract}
Waste is a global problem in all countries, including Indonesia, because the accumulation of waste generated is directly proportional to the number of Indonesian population reached 256 million in 2015. The purpose of this study was to identify factors EFE and IFE waste banks in order to survive and sustainable (sustain). Data collection techniques using $F G D$, expert interviews and questionnaires by WPL Waste Bank customers and their auxiliaries. Data analysis using SWOT and AHP to determine in detail the strategies and priorities for the development activities of the waste bank. The results of the analysis EFE and IFE waste banks shows that this activity is stable and has the potential to grow and develop with consistent with the activities that have taken place, has business planning and development purposes for waste banks, expanding the network of relationships or networking with outsiders and penetration and market development to drive Sales of products of waste processing.
\end{abstract}

Keywords: waste bank, community empowerment, social entrepreneurship, SWOT, AHP

\begin{abstract}
Abstrak: Sampah adalah masalah global di semua negara termasuk Indonesia, sebab akumulasi sampah yang dihasilkan berbanding lurus dengan jumlah penduduk Indonesia yang mencapai 256 juta jiwa pada tahun 2015. Tujuan penelitian ini adalah untuk mengidentifikasi faktor EFE dan IFE bank sampah agar dapat bertahan serta berkelanjutan (sustain). Teknik pengumpulan data menggunakan FGD, wawancara pakar dan pengisian kuesioner oleh nasabah Bank Sampah WPL dan binaannya. Analisis data menggunakan metode SWOT dan AHP untuk menentukan strategi secara detail dan prioritas utama pengembangan kegiatan bank sampah. Hasil analisis EFE dan IFE bank sampah menunjukkan bahwa kegiatan ini berpotensi untuk tumbuh dan berkembang dengan tetap konsisten melakukan kegiatan yang telah berlangsung, memiliki perencanaan bisnis dan tujuan pengembangan bank sampah, memperluas jaringan hubungan atau networking dengan pihak luar serta melakukan penetrasi dan pengembangan pasar untuk mendorong penjualan produk hasil pengolahan sampah.
\end{abstract}

Kata kunci: bank sampah, pemberdayaan masyarakat, kewirausahaan sosial, SWOT, AHP

\footnotetext{
${ }^{1}$ Alamat Korespondensi:

Email: linda.fitrina@gmail.com
} 


\section{PENDAHULUAN}

Sampah menurut World Health Organization (WHO), adalah segala sesuatu yang tidak digunakan, tidak dipakai, tidak disenangi atau sesuatu yang dibuang yang berasal dari kegiatan manusia dan tidak terjadi dengan sendirinya (Chandra, 2007). Sampah dianggap sudah tidak dapat dipergunakan, kadaluarsa, rusak, tidak memiliki nilai dan menjadi timbunan barang. Padahal pandangan dan anggapan tentang sampah ini tidak sepenuhnya benar karena masih banyak sampah yang dapat digunakan kembali, memiliki nilai guna bahkan bernilai jual kembali.

\section{Kementerian Lingkungan Hidup Indonesia} mengeluarkan data tentang rata-rata penduduk yang hidup dan tinggal di Indonesia yang menghasilkan 0,8 $\mathrm{kg}$ sampah atau setara dengan 200 juta $\mathrm{kg} /$ hari dari jumlah total penduduk. Maka diperkirakan pada tahun 2015, timbulan sampah yang dihasilkan sebesar 204.000 ton/hari atau setara 74 juta ton/tahun. Sumber utama sampah di Indonesia adalah rumah tangga, yang secara nasional mencapai $44 \%$ dari total timbulan sampah. Menurut hasil survei yang dilakukan terhadap rumah tangga di Indonesia, teridentifikasi bahwa hanya 1 dari 5 sampling rumah tangga yang melakukan pemilahan sampah.

Tidak mudah untuk merubah perilaku dan kebiasaan masyarakat untuk memilah sampah serta merubah paradigma kumpul - angkut - buang menjadi pengolahan yang bertumpu pada pengurangan sampah dan penanganan sampah. Dibutuhkan sosialisasi dan ketegasan dari pemerintah perihal pengelolaan sampah ini kepada masyarakat, dengan mengeluarkan regulasi dan kebijakan yang terkait dengan sampah, yaitu Undang-Undang Nomor 18 tahun 2008 tentang Pengelolaan Sampah dan Peraturan Pemerintah Republik Indonesia Nomor 81 tahun 2012 tentang Pengelolaan Sampah Rumah Tangga dan Sampah Sejenis Sampah Rumah Tangga.

Menyadari keterbatasan dalam penyediaan fasilitas dan pelayanan di bidang kebersihan serta kemampuan dalam mensosialisasikan program-program lingkungan, pemerintah daerah menjalin kemitraan dengan masyarakat melalui kegiatan bank sampah untuk pengelolaan sampah. Kemitraan ini bertujuan agar masyarakat bersama-sama memecahkan permasalahan mereka sendiri dengan membentuk grup masyarakat yang mandiri dan mampu untuk saling membantu satu dengan yang lain (Wolff, 1992; Hunt, 1994). Kemitraan ini merupakan upaya pemberdayaan masyarakat untuk melaksanakan kegiatan bank sampah, dimana kemitraan ini sangat penting karena masyarakat membutuhkan media yang kuat untuk mempertahankan komitmen mereka berpartisipasi dalam kegiatan kemasyarakatan (Adamson, 2010).

Bank sampah menjalankan fungsi dan tanggung jawab sosial kepada masyarakat, mengedukasi tentang pengelolaan sampah dan kegiatan pemberdayaan masyarakat. Menurut Norman (1999) pemberdayaan masyarakat adalah proses dari sekumpulan individu yang memiliki kesamaan tujuan atau pandangan untuk mengontrol situasi atau keadaan di sekelilingnya, dimana tantangan yang dihadapi adalah bagaimana menginspirasi dan menjaga pemberdayaan tersebut tetap berlangsung dalam suatu komunitas. Menurut Achar (2008) daya tarik utama dari pemberdayaan masyarakat agar warga mau mengikuti dan bergabung dalam kegiatan seperti bank sampah, adalah faktor ekonomi, ekspektasi terhadap peningkatan taraf hidup, dan ketidakpastian atau kepuasan terhadap pekerjaan sebelumnya. Berdasarkan data hasil interview dengan pihak Dinas Kebersihan dan Pertamanan (DKP) kota Depok, sampah memiliki nilai keekonomian yang cukup besar. Rincian data sampah hasil produksi warga Depok dijabarkan dalam Tabel 1.

Jadi lebih tepat jika kegiatan bank sampah ini diarahkan kepada kewirausahaan sosial. Menurut Granados et al. (2011) kewirausahaan sosial adalah kegiatan yang dikerjakan oleh individual atau sekelompok orang yang menciptakan, mempertahankan, membagikan dan menyebarluaskan nilai sosial atau lingkungan dengan cara yang inovatif yaitu dengan mendirikan organisasi yang bersifat sosial, berorientasi keuntungan, berbentuk institusi tertutup atau terbuka.

Pelaksanaan kegiatan Bank Sampah Warga Peduli Lingkungan (WPL) tidak terlepas dari hambatan dan kendala. Hambatan tersebut dapat disebabkan oleh banyak faktor, baik eksternal dan internal. Akibat belum banyak pengkajian dan penelitian yang dilakukan terkait kegiatan bank sampah maka ada kesulitan dalam mengidentifikasi dan merumuskan strategi yang tepat guna dan dapat memenuhi kebutuhan dari penyelenggaraan bank sampah. Oleh sebab itu, perlu untuk melakukan penelitian ini agar dapat menambah 
wawasan dan referensi dalam penyelenggaraan bank sampah dan dapat dijadikan sebagai proyek percontohan bagi banyak pihak yang ingin turut berkontribusi dalam pengelolaan sampah di daerahnya masing-masing.

Penelitian ini bertujuan meninjau dan mendeskripsi pengelolaan dan penanganan sampah di wilayah kota Depok dan di Bank Sampah WPL. Selanjutnya, guna mengidentifikasi faktor internal, faktor eksternal dan pengaruh SWOT terhadap kegiatan Bank Sampah WPL. Di samping itu, merumuskan strategi pengembangan Bank Sampah WPL melalui pemberdayaan masyarakat agar dapat terus berkelanjutan (sustainable).

\section{METOE PENELITIAN}

Penelitian dilakukan di kecamatan Pancoran Mas, Depok dari bulan Juli hingga September 2016. Metode penelitian menggunakan deskriptif dengan studi kasus di Bank Sampah WPL milik bapak Baron Noorwendo dan Ibu Sriwulan. Menurut Sukmadinata (2006), metode penelitian deskriptif adalah sebuah metode yang berusaha mendeskripsikan, mengintepretasikan sesuatu, misalnya kondisi atau hubungan yang ada, pendapat yang berkembang, proses yang sedang berlangsung, akibat atau efek yang terjadi atau kecendrungan yang sedang berlangsung dengan menggunakan prosedur ilmiah untuk menjawab masalah secara aktual. Deskriptif yang dilakukan adalah deskriptif kualitatif yaitu berupa data yang berbentuk kata-kata, catatan observasi, dokumen atau pernyataanpernyataan verbal sebagai hasil dari wawancara atau kuesioner dan bukan dalam bentuk angka. Penelitian dengan menggunakan data kualitatif dilakukan untuk mengembangakn data yang sebelumnya sudah ada dimana hasil data kualitatif berupa kualitas atau proses pencapaian dari suatu kegiatan.

Sumber data primer diperoleh dari wawancara, penyebaran kuesioner dan Focus Group Discussion (FGD) kepada responden tertentu yang telah ditetapkan menggunakan teknik purposive sampling, yaitu pengambilan sample secara sengaja terhadap beberapa responden yang telah ditetapkan berdasarkan jabatan, posisi, pengetahuan dan faktor lain yang menunjukkan kompetensi responden terhadap penelitian (Schindler, 2006). Masih menurut Schindler, responden pakar/ expert adalah yang mengerti permasalahan yang dibahas yang dalam penelitian ini adalah pakar dalam pengelolaan sampah dan kegiatan bank sampah. Data sekunder diperoleh dari sumber internal lembaga Bank Sampah WPL, studi pustaka, media cetak, internet, jurnal, tesis dan informasi lain yang berkaitan dengan topik penelitian (Umar, 2008).

Responden nasabah bank sampah sebagai salah satu sumber data primer. Kuesioner yang disebarkan dan dikembalikan oleh responden yang merupakan nasabah aktif dan tidak aktif berjumlah 70 eksemplar. Tujuan disebarkan kuesioner ini adalah untuk mengetahui apakah pemberdayaan masyarakat melalui kegiatan bank sampah memberikan perubahan dari segi kepekaan/kepedulian, interaksi, komunikasi, pemahaman dan pengaruh (Zimmerman et al. 1992).

Tabel 1. Data sampah kota Depok berdasarkan infrastruktur tempat pengolahan sampah terpadu

\begin{tabular}{lc}
\hline \multicolumn{1}{c}{ Parameter } & Satuan \\
\hline Timbulan sampah saat ini & $3.396 \mathrm{~m}^{3} / \mathrm{hari}^{3}$ \\
Target sampah daur ulang tahun ini & $474,75 \mathrm{~m}^{3} / \mathrm{hari}^{\circ}$ \\
Pengomposan sampah basah (organik) & $369,83 \mathrm{~m}^{3} / \mathrm{hari}^{3}$ \\
Daur ulang sampah kering (nonorganik) & $59,43 \mathrm{~m}^{3} / \mathrm{hari}^{3}$ \\
Sampah B3 dan residu & $474,75 \mathrm{~m}^{3} / \mathrm{hari}$ \\
Recovery Factor (UPS, Bank Sampah, TPA) & $27 \%$ \\
"Pendapatan dari kompos per tahun (asumsi karena kompos tidak untuk dijual)" & $\mathrm{Rp} 2.255 .760 .000$ \\
Pendapatan dari sampah kering (nonorganik) - recycle per tahun & $\mathrm{Rp} 11.130 .163 .200$ \\
\hline
\end{tabular}

Sumber: Hasil wawancara dengan Dinas Kebersihan dan Pertamanan (DKP) kota Depok Kepala Bidang Pelayanan Kebersihan, tertanggal 19 September 2016 
Seluruh hasil kuesioner dari pakar, praktisi dan pemerintahan adalah untuk mengidentifikasi faktor eksternal (peluang dan ancaman) maupun faktor internal (kekuatan dan kelemahan) dalam kegiatan bank sampah (Tabel 2). Menurut David (2009) seluruh faktor tersebut diberikan bobot, ranking/peringkat dan nilai terboboti menggunakan matriks EFE, matriks IFE dan matriks IE. Matriks IE untuk menunjukkan total weight score dalam memposisikan kegiatan bank sampah dan tindakan apa yang harus diambil sebagai strategi pengembangan bank sampah. Analisa menggunakan metode AHP untuk menetapkan faktor strategis prioritas dan aktor utama yang berperan dalam menjalankan prioritas tersebut dan mengambil keputusan sebagai upaya mengembangkan bank sampah.

Teknik pengolahan dan analisis data dalam penelitian ini adalah sebagai berikut: 1) uji validitas dan reabilitas terhadap hasil pengisian kuesioner yang berkaitan dengan pemberdayaan masyarakat; 2) uji tanda hipotesa komparatif untuk membandingkan pemberdayaan masyarakat dengan mengikuti kegiatan bank sampah antara responden aktif dengan nonaktif (pasif); 3) Analisis faktor eksternal dan internal dengan pembobotan nilai dan peringkat; 4) Analisis SWOT berdasarka hasil wawancara dan pengisian kuesioner oleh pakar, praktisi dan pemerintahan; 5) Analisis AHP dengan menggunakan SPSS expert choice untuk menentukan peringkat prioritas tindakan yang harus diambil untuk merumuskan strategi pengembangan.

\section{HASIL}

\section{Karakteristik Responden}

Responden yang diambil untuk mengisi kuesioner peneliti terkait pemberdayaan masyarakat dilakukan secara non probability sampling dengan teknik purposive. Pemilihan responden dilakukan dengan pertimbangan karakteristik yang cocok dengan kebutuhan dalam menjawab tujuan penelitian. Data primer yang didapat dari responden berisikan informasi terkait karakteristik responden yang menjadi nasabah tetap maupun tidak tetap dari Bank Sampah WPL. Pengisian kuesioner oleh masing-masing responden menunjukkan hasil sebagaimana dijelaskan dalam Tabel 3
Uji Validitas, Uji Reabilitas dan Uji Tanda

Perhitungan uji validitas menggunakan person corelation product moment menyatakan bahwa semua indikator pertanyaan sebanyak 25 pertanyaan terkait pemberdayaan masyarakat dalam kegiatan bank sampah dengan indikator kepekaan/kepedulian, interaksi, komunikasi, pemahaman, dan pengaruh semua hasilnya valid, karena nilai $r_{\text {hitung }}>r_{\text {tabel }}$, dimana semua hasil nilai $\mathrm{r}_{\text {hitung }}>0.361$.

Uji reabilitas bertujuan mengetahui kesamaan jawaban yang diberikan dari setiap pertanyaan yang diajukan berulang. Uji ini digunakan untuk melihat konsistensi jawaban yang diberikan. Pengujian reabilitas dari suatu variabel dapat dilakukan dengan melihat nilai Cronbach Alpha. Menurut Gozali (2005), suatu instrumen dikatakan handal apabila nilai Cronbach Alpha >0.60. Hasil perhitungan uji reabilitas adalah 0,756 sehingga reabilitasnya terpenuhi.

Hasil Uji Tanda Komparasi terhadap pemberdayaan antara masyarakat aktif dan nonaktif dalam pelaksanaan kegiatan bank sampah masyarakat menyangkut indikator kepekaan/kepedulian, interaksi, komuniksi, pemahaman dan pengaruh. Hasilnya tidak menunjukkan ada perbedaan pada masing-masing indikator (nilai diatas < 0,05) kecuali indikator komunikasi ada perbedaan (nilai dibawah $<0,05$ ) sehingga masyarakat menilai pelaksanaan kegiatan bank sampah WPL belum optimal.

\section{Analisis Faktor Eksternal dan Faktor Internal}

Hasil perhitungan bobot, peringkat dan nilai bobot terhitung dari masing-masing variabel menunjukkan nilai dalam Tabel 4 (matrik ekternal) dan Tabel 5 (matrik internal). Faktor eksternal terdiri dari variabel peluang dan ancaman. Peluang harus dapat dimanfaatkan untuk pengembangan dan peningkatan kegiatan di bank sampah WPL. Peluang tertinggi adalah perubahan perilaku masyarakat dalam memilah sampah organik dan non organik $(0,38)$, dimana hal tersebut didukung komitmen pemerintah $(0,356)$ dalam kegiatan pengelolaan sampah maupun pemberlakuan regulasi dan kebijakan $(0,267)$ yang mendukung pertumbahan bank sampah. Tawaran kerja sama dari perusahaan/ korporasi, pihak swasta untuk menjalankan program CSR atau kegiatan kemasyarakatan $(0,216)$. Kemajuan di bidang IT dan media sosial untuk sosialisasi kegiatan, promosi, menghubungkan komunitas dan 
berbagi informasi $(0,189)$. Munculnya bank sampah membuka peluang usaha industri kreatif berbahan baku sampah $(0,15)$ yang masih sangat luas pasarnya karena belum banyak pihak yang berusaha dan fokus di indutri ini sehingga prospektif untuk ditekuni $(0,144)$.

Ancaman adalah segala sesuatu yang harus dihindari atau dikurangi dampaknya terhadap kegiatan bank sampah. Ancaman terbesar adalah kurangnya minat, ketertarikan dan kebutuhan masyarakat untuk bergabung dan terlibat dalam kegiatan bank sampah $(0,17)$. Pemenuhan pendampingan dan pelatihan dalam penyelenggaraan bank sampah masih sangat kurang $(0,168)$. Kurangnya ketersediaan fasilitas dan pelayanan kebersihan bagi masyarakat memiliki dampak terhadap lingkungan dan penanganan sampah $(0,156)$. Jika konsistensi semua pihak yang terlibat dalam kegiatan bank sampah tidak terpenuhi maka keberlangsungan dan perkembangan bank sampah tidak akan tercapai $(0,094)$. Pemberian apresiasi terhadap keberhasilan pelaksanaan kegiatan/program di bidang pengelolaan sampah masih jarang $(0,082)$. Kolaborasi dengan pihak ketiga/luar tidak berlanjut karena berbasis proyek dan berupa bantuan pendanaan $(0,053)$. Kurang maksimalnya serapan pasar terhadap produk industri kreatif karena selera dan permintaan konsumen belum terpenuhi $(0,039)$. Rendahnya penjualan produk industri kreatif berdampak pada patokan harga jual yang fluktuatif.

Tabel 2. Jumlah responden dari kalangan pakar

\begin{tabular}{lll}
\hline \multicolumn{1}{c}{ Responden } & \multicolumn{1}{c}{ Posisi } & Jumlah \\
\hline Pendiri Bank Sampah WPL & Pakar di bidang Bank Sampah & 1 orang \\
Pengelola Bank Sampah WPL & Pakar di bidang Bank Sampah & 1 orang \\
Ketua Asosiasi Bank Sampah Kota Depok & Praktisi di bidang Bank Sampah & 1 orang \\
Kepala Subbagian Umum & Pemerintahan dari DKP Kota Depok & 1 orang \\
Kepala Bidang Pelayanan Kebersihan & Pemerintahan dari DKP Kota Depok & 1 orang \\
\hline
\end{tabular}

Tabel 3. Karakteristik responden Bank Sampah WPL

\begin{tabular}{lcc}
\hline \multicolumn{1}{c}{ Karakteristik } & Jumlah & $\%$ \\
\hline Jenis Kelamin & 4 & $5,7 \%$ \\
Laki-laki & 66 & $94.3 \%$ \\
Perempuan & & \\
Usia & 3 & $4,3 \%$ \\
$21-30$ tahun & 22 & $31,4 \%$ \\
31-40 tahun & 35 & $50 \%$ \\
$41-50$ tahun & 10 & $14,3 \%$ \\
$>$ 50 tahun & & \\
Lama domisili & 8 & $11.4 \%$ \\
5-10 tahun & 16 & $22.9 \%$ \\
$11-20$ tahun & 10 & $14.3 \%$ \\
20-30 tahun & 36 & $51.4 \%$ \\
$>30$ tahun & & \\
Pendidikan & 37 & $52,9 \%$ \\
SD/SMP & 26 & $37,1 \%$ \\
SMA/Sederajat & 7 & $10 \%$ \\
Diploma/S1 & & \\
\hline
\end{tabular}

\begin{tabular}{lcc}
\hline \multicolumn{1}{c}{ Karakteristik } & Jumlah & $\%$ \\
\hline Profesi & & \\
PNS/Pegawai Swasta & 4 & $5,7 \%$ \\
Buruh/Karyawan Lepas & 4 & $5,7 \%$ \\
Wirausaha/Bisnis Pribadi & 10 & $14,3 \%$ \\
lbu Rumah Tangga & 52 & $74,3 \%$ \\
Pengeluaran/bulan & & \\
$<1$ juta & 36 & $51,4 \%$ \\
1-3 juta & 27 & $38,6 \%$ \\
3-5 juta & 7 & $10 \%$ \\
Pembelanjaan terbesar/bulan & & \\
Bahan makanan & 35 & $50 \%$ \\
Makanan jadi & 4 & $5,7 \%$ \\
Kebutuhan pribadi & 30 & $42,9 \%$ \\
Barang konsumtif & 1 & $1,4 \%$ \\
\hline
\end{tabular}




\section{Peluang}

Undang-undang dan Peraturan Pemerintah tentang Bank Sampah

$0,089 \quad 3 \quad 0,267 *$

Komitmen Pemerintah untuk menjalankan kegiatan \& bermitra dengan masyarakat dalam

0,089

4

0,356 pengelolaan sampah

Potensi perubahan perilaku masyarakat dalam mengelola sampah

$\begin{array}{ccc}0,095 & 4 & 0,38 \\ 0,050 & 3 & 0,15 \\ 0,048 & 3 & 0,144 \\ 0,072 & 3 & 0,216 \\ 0,063 & 3 & 0,189\end{array}$

\section{Ancaman}

Ketersediaan sarana, prasarana dan aparat kebersihan belum mencukupi dan memadai untuk mengimbangi pertambahan penduduk

Kerja sama lintas sektor untuk memenuhi kebutuhan pembinaan dan pelatihan SDM belum terlaksana

Keterlibatan dan partisipasi masyarakat belum optimal

$0,078 \quad 2 \quad 0,156$

Apresiasi masyarakat terhadap industri kreatif pemanfaatan sampah masih rendah

$0,084 \quad 2 \quad 0,168$

Fluktuasi harga di pihak ketiga (pengepul) berpengaruh terhadap keuangan

0,041

Persaingan dalam pemasaran produk industri kreatif

0,025

0,082

Kerja sama/kolaborasi dengan pihak ketiga / luar tidak berkelanjutan (sustain)

0,039

0,025

Konsistensi pemerintah, masyarakat dan stakeholders dalam menjalankan kegiatan bank

0,053

0,039 sampah

0,094

\begin{tabular}{llll}
\hline Jumlah & 1,000 & $2,489 *$ \\
\hline
\end{tabular}

Keterangan: *) Nilai hasil olah data kuesioner

Faktor internal terdiri dari kekuatan yang dimiliki oleh Bank Sampah WPL dalam melaksanakan kegiatan dan operasional. Pendiri dan pemilik bank sampah WPL memiliki visi, misi yang kuat serta seorang yang visioner menjadi kekuatan utama bagi kegiatan Bank Sampah WPL $(0,36)$. Lembaga ini mampu memberdayakan masyarakatuntukbergabungdanmelakukanpengelolaan sampah melalui kegiatan bank sampah $(0,336)$. Fungsi dan peranan Bank Sampah WPL adalah mengedukasi masyarakat agar merubah perilaku, paradigma dan cara pandang terhadap sampah $(0,316)$. Kerja sama sebagai tim dan kemampuan berinteraksi satu dengan yang lain turut berperan $(0,225)$. Menjalin dan menjaga hubungan atau networking dengan semua pihak baik pemerintahan, tokoh masyarakat, pengusaha dan stakeholders, membantu pengembangan bank sampah $(0,132)$. Kemampuan dan pemahaman dalam bidang IT dan media sosial dapat membantu keberlangsungan dan promosi kegiatan $(0,066)$. Apresiasi dan pengakuan atas prestasi dalam penyelenggaraan bank sampah memotivasi semua pihak dalam melanjutkan dan mengembangkan kegiatan bank sampah $(0,051)$.
Faktor kelemahan adalah faktor yang harus diperbaiki atau ditingkatkan dalam kegiatan Bank Sampah WPL. Kelemahan utama adalah kesulitan dalam memenuhi bahan baku dari masyarakat untuk industri kreatif $(0,19)$. Kurangnya perencanaan bisnis dan tujuan pengembangan menjadi salah satu kelemahan kegiatan bank sampah $(0,18)$. Kebutuhan pendampingan dan pelatihan SDM belum terpenuhi $(0,10)$. Kreativitas, dan inovasi dalam mengelola sampah kurang terasah $(0,136)$ sehingga berpengaruh pada ketrampilan dan kemampuan pengrajin dalam berproduksi $(0,128)$. Hasil produksi yang tidak memenuhi selera dan permintaan pasar $(0,044)$ berimbas pada penjualan produk hasil pengelolaan sampah yang kurang sehingga tidak menghasilkan profit dan memenuhi kebutuhan dana operasional $(0,089)$.

\section{Analisis Matriks Internal Eksternal}

Hasil perhitungan bobot dan peringkat yang menghasilkan skala terboboti dari masing-masing variabel menunjukkan nilai matriks eksternal sebesar 2,489 merupakan rata-rata dari semua faktor eksternal yangteridentifikasidengannilaikekuatanyangtergolong 
sedang. Artinya peluang dan ancaman yang terjadi pada pelaksanaan kegiatan Bank Sampah WPL tidak terlalu mendominasi. Masih dalam batasan pengaruh yang wajar dan cendrung stabil. Sedangkan untuk kondisi faktor internal, nilai matriks menunjukkan angka 2,713 yang berarti diatas faktor eksternal namun masih masuk dalam golongan sedang atau rata-rata. Matriks Internal Eksternal (IE) selengkapnya pad Tabel 6.
Berdasarkan nilai terboboti tersebut, maka menurut David (2009), posisi dari Bank Sampah WPL berada di posisi $\mathrm{V}$ yang termasuk posisi stabil (jaga dan pertahankan). Jadi, kegiatan Bank Sampah WPL ini dapat dikembangkan dengan perbaikan dan perubahan mengikuti strategi pengembangan yang telah diidentifikasi. Untuk posisi ini, strategi yang dapat ditingkatkan adalah penetrasi pasar dan pengembangan produk adalah dua strategi yang umum digunakan untuk divisi tipe ini.

Tabel 5. Matriks faktor internal

Faktor internal

\section{Kekuatan}

Memiliki visi dan misi

Memiliki tokoh panutan/pemimpin yang visioner

Kelompok masyarakat/pengelola Bank Sampah yang solid dan berkeinginan untuk maju

Memiliki jaringan/networking yang luas dengan banyak pihak terkait

Memanfaatkan teknologi informasi dan media sosial untuk sosialisasi kegiatan

Memiliki tanggung jawab sosial dan peranan mengedukasi masyarakat

Mampu menggerakkan dan memberdayakan masyarakat

Mendapat pengakuan dan penghargaan dari pihak/instansi terkait dan masyarakat umum atas pencapaian dan hasil kerja yang sudah dicapai

\section{Kelemahan}

Belum memiliki perencanaan dan tujuan pengembangan usaha

Kuranganya SDM yang terampil dan terlatih

Kurangnya kreativitas dan inovasi dalam produksi industri kreatif yang memanfaatkan sampah

Pelatihan dan pembinaan yang sesuai dengan kebutuhan belum didapatkan

Keterbatasan mendapatkan bahan baku untuk produksi industri kreatif

Mengikuti selera dan permintaan pasar/konsumen belum dapat terpenuhi

Keterbatasan dana dalam menjalankan kegiatan operasional

Jumlah

Keterangan: *) Nilai hasil olah data kuesioner

Tabel 6. Hasil matriks internal eksternal

Total nilai EFE yang dibobot

\begin{tabular}{ccccc} 
& & & Total nilai IFE yang dibobot & Lemah \\
\cline { 2 - 4 } & & Kuat & Rata-Rata & $1,0-1,99$ \\
& Tinggi & $3,0-4,0$ & $2,0-2,99$ & III \\
Total nilai EFE yang \\
dibobot
\end{tabular}




\section{Analisis SWOT}

Rumusan strategi pengembangan Bank Sampah WPL dilakukan dengan pendekatan analisis matriks SWOT untuk menetapkan strategi pengembangan yang tepat dan lebih detail di tingkat pelaksanaan. Penjelasan tentang strategi pengembangan pada Gambar 1.
Mengkombinasikan antara peluang-kekuatan, peluang kelemahan, ancaman-kekuatan dan ancamankelemahan. Bank Sampah WPL memanfaatkan peluang yang ada dengan kekuatan utama yang dimiliki, memperkecil kelemahan dan mengaliminir ancaman dalam kegiatan bank sampah.

\begin{tabular}{|c|c|c|}
\hline Faktor eksternal & $\begin{array}{l}\text { Strength }(\mathrm{S}) \\
\text { 1. Memiliki visi dan misi }(0,36) \\
\text { 2. Tokoh panutan/pemimpin yang } \\
\text { visioner }(0,36) \\
\text { 3. Pemberdayaan masyarakat } \\
(0,32) \\
\text { 4. Fungsi sosial dan edukasi } \\
\text { masyarakat }(0,32) \\
\text { 5. SDM yang solid dan mampu } \\
\text { bekerjsama }(0,21) \\
\text { 6. Networking/jaringan hubungan } \\
\text { (0,13) } \\
\text { 7. Pengakuan dan apresiasi atas } \\
\text { pencapaian }(0,05) \\
\text { 8. Pemahaman dan pemanfaatan } \\
\text { IT }(0,01)\end{array}$ & $\begin{array}{l}\text { Weaknesses }(\mathrm{W}) \\
\text { 1. Belum memiliki perencanaan bisnis } \\
\text { dan tujuan pengembangan }(0,19) \\
\text { 2. Keterbatasan bahan baku }(0,18) \\
\text { 3. Kreativitas dan inovasi }(0,14) \\
\text { 4. SDM yang terampil dan terlatih } \\
(0,13) \\
\text { 5. Pelatihan dan pendampingan }(0,10) \\
\text { 6. Keterbatasan dana }(0,09) \\
\text { 7. Kurang dapat mengikuti selera dan } \\
\text { permintaan konsumen }(0,01)\end{array}$ \\
\hline $\begin{array}{l}\text { Opportunities }(\mathrm{O}) \\
\text { 1. Perubahan perilaku masyarakat }(0,38) \\
\text { 2. Komitmen dalam pelaksanaan program } \\
(0,36) \\
\text { 3. Regulasi dan perundang-undangan }(0,27) \\
\text { 4. Penawaran program dari pihak ketiga } \\
(0,22) \\
\text { 5. Pemanfaatan IT dan sosial media }(0,19) \\
\text { 6. Pangsa pasar industri kreatif }(0,15) \\
\text { 7. Kewirausahaan sosial }(0,14)\end{array}$ & $\begin{array}{l}\text { Strategi S-O } \\
\text { 1. Meningkatkan kegiatan } \\
\text { internal bank sampah untuk } \\
\text { mengakomodir perubahan } \\
\text { perilaku masyarakat terhadap } \\
\text { sampah (O1,S3) } \\
\text { 2. Meningkatkan kemampuan } \\
\text { dan ketrampilan SDM dengan } \\
\text { memanfaatkan program training } \\
\text { dari pihak luar/ketiga (O4, S5) } \\
\text { 3. Mempeluas jaringan hubungan } \\
\text { (networking) untuk menjangkau } \\
\text { pangsa pasar industri kreatif } \\
\text { yang lebih besar (O6, S6) }\end{array}$ & $\begin{array}{l}\text { Strategi W-O } \\
\text { 1. Mengatasi keterbatasan bahan } \\
\text { baku industri kreatif dengan lebih } \\
\text { banyak mengajak, mengedukasi } \\
\text { dan membina kelompok masyarakat } \\
\text { tentang kegiatan bank sampah (O1, } \\
\text { W2) } \\
\text { 2. Berkomitmen dalam membuat dan } \\
\text { menjalankan perencanaan bisnis (O2, } \\
\text { W1) }\end{array}$ \\
\hline $\begin{array}{l}\text { Threats }(\mathrm{T}) \\
\text { 1. Keterlibatan dan partisipasi masyarakat } \\
\text { yang kurang }(0,17) \\
\text { 2. Kurangnya penyelenggara pelatihan dan } \\
\text { pendampingan }(0,17) \\
\text { 3. Ketersediaan fasilitas kebersihan terbatas } \\
(0,16) \\
\text { 4. Konsistensi pelaksanaan kegiatan }(0,09) \\
\text { 5. Kurangnya apresiasi terhadap industri } \\
\text { kreatif hasil sampah }(0,08) \\
\text { 6. Kolaborasi/kerja sama yang tidak } \\
\text { berkelanjutan dengan pihak luar }(0,05) \\
\text { 7. Kurangnya pemasaran produk industri } \\
\text { kreatif }(0,04) \\
\text { 8. Fluktuasi harga }(0,03)\end{array}$ & $\begin{array}{l}\text { Strategi S-T } \\
\text { 1. Konsistensi dari pemilik bank } \\
\text { sampah dalam menjalankan } \\
\text { kegiatannya (T4, S1) } \\
\text { 2. Meningkatkan penggunaan } \\
\text { IT untuk kegiatan pemasaran/ } \\
\text { promosi produk industri kreatif } \\
\text { (T7, S8) } \\
\text { 3. Menjalakan misi edukasi } \\
\text { dengan memberikan pelatihan } \\
\text { dan pendampingan tentang } \\
\text { pengelolaan sampah kepada } \\
\text { masyarakat (T2, S4) }\end{array}$ & $\begin{array}{l}\text { Strategi W-T } \\
\text { 1. Pemenuhan permintaan dan } \\
\text { selera konsumen terhadap produk } \\
\text { industri kreatif untuk meningkatkan } \\
\text { pemasaran/penjualan produk } \\
\text { (T7,W7) } \\
\text { 2. Menjaga kolaborasi dengan } \\
\text { pihak luar, khususnya dalam } \\
\text { penyelenggaraan pelatihan dan } \\
\text { pendampingan yang dapat mengasah } \\
\text { ketrampilan dan kreativitas SDM } \\
\text { (T6, W4, W5) }\end{array}$ \\
\hline
\end{tabular}

Gambar 1. Matriks analisis SWOT 


\section{Analisis AHP}

Analisis AHP pada penelitian ini bertujuan mendapatkan pendapat atau masukan dari pakar baik dari pemilik, masyarakat, pemerintahan dan praktisi, terkait prioritas strategi yang harus dilakukan untuk pengembangan kegiatan bank sampah. Hasil analisis diperoleh dari pengisian kuesioner oleh pakar yang kemudian diolah menggunakan software expert choice untuk penelitian dengan analisis AHP. Pakar yang dipilih terdiri dari lima orang responden yang memiliki kompetensi dan pemahaman tentang kegiatan pengelolaan sampah dan kegiatan bank sampah di kota Depok. Expert menurut Cooper dan Schindler (2006) adalah responden yang mengerti akan permasalahan yang dibahas yaitu pengelolaan sampah melalui kegiatan bank sampah. Respond dari expert yang diolah juga untuk menentukan faktor utama dengan keunggulan yang harus diprioritaskan dan pihak mana yang berperan dalam mengambil keputusan. Hierarki strategi pengembangan Bank Sampah WPL dijabarkan dalam Gambar 2.

\section{Implikasi Manajerial}

Bank Sampah WPL memiliki beberapa tahapan atau proses yang harus dijalankan dalam upaya mengembangkan kegiatannya. Tanpa meninggalkan visi dan misi utama, yaitu "Build the Locals" berupa tanggung jawab sosial, edukasi dan pemberdayaan masyarakat, Bank Sampah WPL harus memfokuskan kewirausahaan dalam kegiatan "Garbagepreneurship" agar kegiatan bertahan dan berkelanjutan (sustainable). Implikasi managerial yang dapat diaplikasikan kepada Bank Sampah WPL ini adalah antara lain membuat perencanaan usaha (business plan) dan menetapkan tujuan pengembangan sebagai upaya pembenahan dan perbaikan Bank Sampah WPL. Dees et al. (2001) menyebutkan jika perencanaan bisnis untuk usaha sosial menyediakan berbagai manfaat, misalnya, dengan menciptakan "kejelasan arah", "pengetahuan tentang pasar", "komitmen yang kuat dari para stakeholder" dan "menarik investasi". Selanjutnya, melakukan kerja sama dan jalinan hubungan (networking) dengan usaha/kegiatan sejenis maupun lintas sektor, baik dengan instansi pemerintah, kedinasan, dan pihak swasta yang dapat bekerja sama dalam memenuhi kebutuhan pelaksanaan kegiatan bank sampah WPL. Di samping itu, perlunya pemanfaatan program yang ditawarkan oleh lembaga, instansi, swasta, perusahaan/ korporasi sebagai perwujudan tanggung jawab sosial kepada masyarakat atau sering disebut Program CSR (corporate social responsibility). Menurut Cornelius et al. (2008) kegiatan CSR berbasis masyarakat lebih sering berkembang baik di sektor swasta usaha kecil menengah (UKM). Penetrasi pasar dengan menghasilkan deferensi produk yang lebih banyak memanfaatkan bahan baku sampah dari masyarakat dan perluasan segmentasi pasar yang dapat membantu untuk mendorong penjualan atas produk industri kreatif.

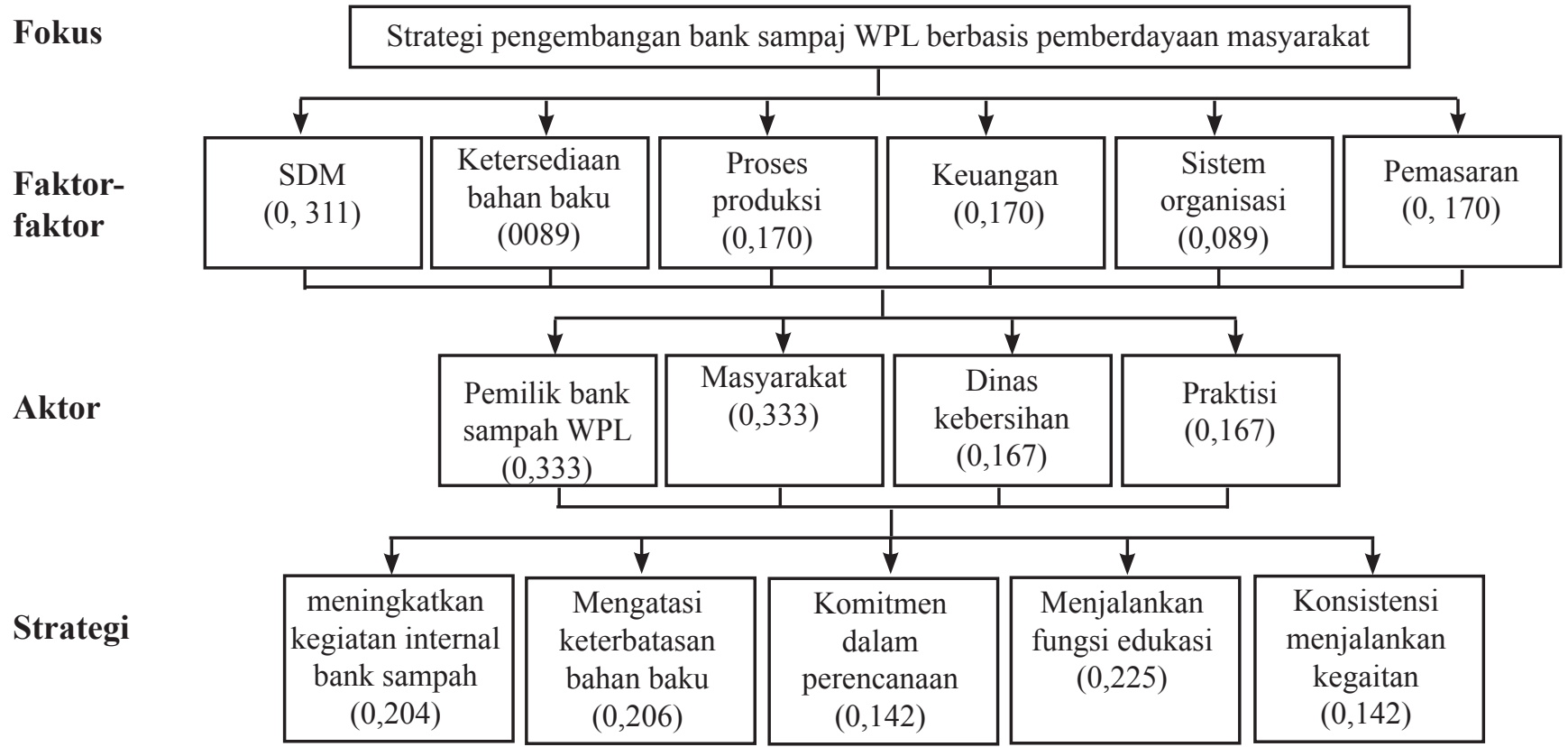

Gambar 2. Hierarki strategi pengembangan Bank Sampah WPL 


\section{KESIMPULAN DAN SARAN}

\section{Kesimpulan}

Berdasarkan penelitian dan kajian terhadap faktor internal dan eksternal, analisis SWOT dan analisis AHP, maka dapat disimpulkan bahwa kegiatan Bank Sampah WPL relatif stabil dan bertahan serta berpotensi untuk dikembangkan dengan menggunakan faktor internal dan eksternal yang dimilikinya dengan lebih mengoptimalkan pemberdayaan masyarakat khususnya kaum perempuan yang mendominasi kegiatan yang diselenggarakan dalam masayarakat. Strategi pengembangan yang paling dibutuhkan oleh Bank Sampah WPL merupakan kolaborasi dari kekuatan internal organisasi dengan peluang serta perubahan eksternal yang terjadi saat ini di luar kegiatan bank sampah. Diperlukan antisipasi, pembenahan dan perbaikan terhadap ancaman yang terjadi dan kelemahan yang dimiliki oleh bank sampah agar tidak memengaruhi pelaksanaan kegiatannya. Menetapkan prioritas strategi pengembangan pada bidang SDM, produksi, pemasaran dan pendanaan yang menjadi kendala utama dalam pengembangan Bank Sampah WPL.

\section{Saran}

Kegiatan Bank Sampah memberikan manfaat positif bagi masyarakat serta mampu memberikan nilai tambah bagi yang menjalankannya baik dari segi ekonomi, sosial budaya, pendidikan dan kemasyarakatan, sehingga sepantasnya didukung dan didorong agar semakin berkembang. Memberikan kesempatan dan percontohan kepada pihak luar untuk mengadopsi kegiatan Bank Sampah WPL dan menjalankannya di daerah yang belum memiliki sistem dan kelembagaan yang membantu dalam pengelolaan sampah. Perlu penelitian lebih lanjut tentang perilaku dan cara pandang masyarakat terhadap pengelolaan sampah agar lebih memperkaya penelitian sebelumnya sehingga mampu lebih memberdayakan masyarakat untuk keikutsertaannya dan partisipasi dalam kegiatan bank sampah.

\section{DAFTAR PUSTAKA}

Adamson D. 2010. Sociology, Social Services And Welfare. The International Journal of Sociology and Social Policy 30(3/4): 114-126. https://doi. org/10.1108/01443331011033319.

Annonymous. 2012. Buku Profil Bank Sampah 2012. Kementerian Lingkungan Hidup http:// www.menlh.go.id/profil-bank-sampahindonesia-2013/.

Chandra B. 2007. Pengantar Kesehatan Lingkungan. Jakarta: Penerbit Buku Kedokteran.

Cooper DR, Schindler PS. 2006. Marketing Research. New York (US): McGraw- Hill.

Cornelius N, Todres M, Janjuha-Jivraj S. et al. 2008. Corporate Social Responsibility and the Social Enterprise. Journal of Business Ethics 81(2): 355-370. https://doi.org/10.1007/s10551-0079500-7.

David FR. 2009. Strategic Management (Buku 1, Edisi 12, alih bahasa oleh Dono Sunardi). Jakarta: Penerbit Salemba Empat.

Dees JG, Emerson J, Economy P. 2001. Enterprising Non-profits: A Toolkit for Social Entrepreneurs. Di dalam: Business planning training for social enterprise. Social Enterprise Journal 4(1):5773.

Granados ML, Hlupic V, Coakes E, Mohamed S. 2011. Social enterprise and social entrepreneurship research and theory. Social Enterprise Journal 7(3): 198-218. https://doi. org/10.1108/17508611111182368.

Hunt G. 1994. Ethnography and the pursuit of culture: The use of ethnography in evaluating the community partnership program. Journal of Community Psychology CSAP Special Issue: $52-60$.

Norman L. 1999. Community Empowerment Approaches to Environmental Stewardship. Ottawa: The University of Guelph

Sukmadinata. 2006. Metode Penelitian Pendidikan. Bandung: Remaja Rosdakarya.

Umar H. 2008. Strategic Management in Action. PT Gramedia Pustaka Utama. Jakarta

Zimmerman MA, Israel BA, Schulz A et al. 1992. Further explorations in empowerment theory: An empirical analysis of psychological empowerment. American Journal of Community Psychology 20(6): 707-727. https://doi. org/10.1007/BF01312604. 